\title{
A review on weaknesses and strengths of delivering Mehr housing project in terms of achieving economical goals
}

\author{
Ali Karshenasan ${ }^{a}$ and Mahsa Beiranvand ${ }^{b^{*}}$
}

${ }^{a}$ Asisstant Professor, Department of Economics, Lorestan University, Khorram Abad, Iran

${ }^{b}$ Master of Business Administration, Department of Management,Payame Noor University,PO BOX 19395-3697,Tehran,IRAN

\section{H R O N I C L E A B S T R A C T}

Article history:

Received May 15, 2013

Received in revised format

25 June 2013

Accepted 7 August 2013

Available online

August 72013

Keywords:

Mehr housing project

Construction project

Weaknesses and strengths of

delivering

Economic assessment

\begin{abstract}
Housing is one of the most important sections of development in a country and its economic importance has put it in the center of attention. It can cause rise and depression of habitation by its extended economic aspects. Mehr Housing plan is a state run housing project in most cities started 2007 in Iran to protect and provide cheap housing for poor people and young couples. Mehr housing project by its large scale and wide dimensions can affect the society's economy. Therefore, to investigate weaknesses and strengths of this project in terms of economic and applying necessary reformation can increase the success probability of this project. For this purpose, this study assess the weaknesses and strengths of Mehr housing of province of Khorram Abad in Iran for achieving economic goals and also presents solutions to better access to these goals. Time scope of the present study is 6 months of 2011 and the second 3 months of 2012. The methodology is applicable in terms of goal and is descriptive survey in terms of nature. In this study, a combined method of interviewing to experts and distributing a questionnaire among the applicants of Mehr housing has been used for data collecting. Among strengths of Khorram Abad in economic section, employment and urban landfill pattern reformation can be implied. In addition, among weaknesses of this project are lack of proper first design and technical justification of the project and use of only 2 shabby fabrics.
\end{abstract}

\section{Introduction}

One of the primary concerns in modern society is to have stable life with house and shelter. Many young people wish to get married and have joyful family but suffer from shortage of saving to rent or purchase house for their future lives. This has created tremendous crisis in modern society especially in Iran (Varesi, 2009). The relationship of housing with other economic section is considered as a 
proper tool to achieve economic policies (Azizi, 2004). The importance of housing in economy is evident. In association with the effects of housing on macroeconomics, it can be said that the rate of investment, productivity, employment, and housing prices included in factors, which affect macroeconomics. Increase of investment in housing leads to increase of investment of economic activities on other sectors such as increase in productivity, employment, etc. Housing, in national scale, is effective on inflation, labor work dynamic, and government budget through tax and subsides (Dehghan, 2010). In Iran, Mehr housing can be considered as a new approach in the field of housing in the country, which influences the whole economy and particularly housing sector by using great volume of production inputs. In addition, this project plays a key role in national economic flow, employment, and financial basket of thousand urban and rural families that are applicant to provide personal house (Nasiri Taj Abadi, 2011). Therefore, according to the role of Mehr housing in economy, this article investigates the economic effects and outcomes of Mehr housing in province of Khorram Abad and identifies the weaknesses and strengths of it in terms of economic aspects, and finally presents reformation recommendation to overcome those weaknesses.

\subsection{Hypothesis:}

$>$ The mehr housing project is successful in terms of access to economic goals ${ }^{1}$.

$>$ The mehr housing project has significantly affected construction industry positively in terms of cost management and scale economy.

$>$ The mehr housing project has significantly affected key macroeconomic indices including, employment, householders access to independent home, housing inflation and quality of housing.

\subsection{Economic aspects of Mehr housing}

\section{- Increasing national production and economic development}

The trend of house production during current decade shows that about 600 to 800 thousands constructional permissions have been issued, annually. Therefore, 550 thousands constructional permission as Mehr housing during recent months, and increase of construction section rather than agricultural and oil groups in economic development, indicate the extension of this project. It also suggests that the trend of its implementation will lead to increase of GDP, economic prosperity in other related sectors associated with housing and will prevent from economic declination during future years (Soomelou, 2010).

\subsubsection{Increase of employment}

Regarding the employing nature of housing sector for providing direct professions and having the $2^{\text {nd }}$ and $4^{\text {th }}$ place of providing indirect professions, Mehr housing can play a significant role in prevention and inhibition of unemployment. Nowadays, per $57 \mathrm{~mm}$ of houses, 1 person of direct profession and 0.24 person of indirect profession are created, so that according to the meters of Mehr housing there has been 2170000 professions involved in this project either directly or indirectly (Soomelou,2010).

\subsubsection{Investment}

According to the Mehr housing program, 1 million houses should be constructed, so it is predicted that after complete implementation of the project, about 320,000 billion Rials investment will be

\footnotetext{
${ }^{1}$ Economic goals of mehr housing plan which determined law were as: inverting home from capital good to consumption good, observing technical and engineering standards, quality of construction, national product and economic growth, access to independent home index, job creation, investment, energy frugality by householders, land frugality, financing housing.
} 
provided. This amount of money is more than the whole investment done in housing section in 2009, which is 306,000 billion Rials by current price (Chegini, 2010).

\subsubsection{Control of general level of prices and houses price}

Attracting the cash of households and bank facilities in the process of building houses plays an important role to control general level of prices. Paying the bank facilities back will prevent inflation over time. Although Mehr housing pushes the cash flow to the housing sector by canalizing supports and credential facilities for supplying houses as well as monetary spastically policies, it has no deconstructive effect on housing market and leads to control of housing price by decreasing present prices and cumulative for increasing supply (Soomelou, 2010).

\subsubsection{Increase of access to house index}

Reducing the expectancy period to access house for 4 deciles of the population is a by-product of Mehr housing project. This is due to the elimination of landfill price from produced price of houses, effective tracking and management of the government in building of Mehr housing, and improving credential facilities for construction so that, the average expectancy period to access house will be reduced (Chegini, 2010).

\subsubsection{Improving household members in a habitation unit}

Household members' index associated with house production in Iran has been reduced to 1.07 in urban regions and 1.1 in rural regions and it will be effective to reduce Household members' index in low-income groups (Soomelou, 2010).

\subsubsection{Demand of low-income household}

A part of Mehr housing cost should be paid by applicants, so the applicants who are not able to pay the cost, namely third, fourth, and fifth deciles of people are supported. On the other hand, demands of households of third and fourth deciles who have not effective demand in recent conditions due to the lack of sufficient financial affording, is responded by Mehr housing project.

\subsubsection{Economic justice promotion}

Housing price share index of household cost basket in developed countries is about $20 \%$, and this rate is averagely $30 \%$ in Iran and 50 to $70 \%$ in metropolises for low-income groups that simultaneously reduce household costs and increase income by implementing Mehr housing policies (Soomelou,2010).

\subsubsection{Building quality promotion}

Obligation to comply national regulations for building all units of Mehr housing and monitoring of urbanization organizations on them can promote the quality of built houses and increase indexes such as durable houses (Soomelou, 2010).

\subsection{Mehr housing and industrialization}

Industrialization in building is a complex and extensive subject, including culture, diversity in applying tastes, and technical contexts such as earthquakes that all should be surveyed according to the present conditions of the country. During the past decade, industrial constructions have been improved qualitatively and quantitatively all over the world and particularly in developed countries. Indeed, this industry has been successful to increase the quality and durability of prefabricated materials, so that these structures are competitive to expensive fixed house structures. Prefabricated 
house structures industry is a unique method to deal with the crisis of not affordability of families' shopping; since this industry at first shows its efficiency in traditional kind of building (Nikzadfar, 2011).

Another important issue is to consider Mehr housing project as a mass production work and this helps us reduce the cost of production, increase the quality of materials and construction, significantly (Khajepour, 2011). Some of industrial construction methods in Mehr housing projects include, the method of prefabricated concrete beam and column using Halcour roof, the method of vertical flat durable insulator bars (vertical and horizontal), the system of tunnel housing (Shams method), implementing industrial bolt and nut steel, cold rolled light steel bars, semi-prefabricated buildings with single plates of sandwich walls, double layer windows (upvc), and Anti-theft doors (Janfeshan, 2010).

\subsection{Mehr housing and saving energy}

Zero waste of energy: Nowadays saving and optimal consumption of energy resources in most countries is considered as a priority and national security issue. For this reason, many families look for a cheap house that consumes the minimum energy. According to the performed surveys, energy consumption of the prefabricated houses is at least 50 percent less than fixed and traditional houses. Thus, experts of habitation predicted that within the next 10 to 15 years, building prefabricated houses with zero waste of energy will be possible technically and economically (Nikzadfar, 2011).

Regarding to the necessity of saving energy in Mehr housing projects, along with informing people to change their attitude about energy, using industrial modern methods leads to obtain this goal and achieve listed chapters in $19^{\text {th }}$ topic of national regulations of construction. In addition to prevent waste of energy in building, it causes to reduce energy costs in habitation, and it can be another positive effect of Mehr housing in improvement and reformation of construction culture. Regarding to the government intention to make the prices real including cost of water and according to the severe dehydration in the country, Mehr housing is an important test for the stakeholders in order to indicate energy saving methods (Peyvandi \& Dadashi, 2009).

\subsection{Mehr housing role in landfill productivity and urban life quality promotion}

The information and specification of over 300,000 houses in 18 cities of 12 provinces of the country are analyzed as sample, in the field of Mehr housing role in landfill productivity. We observe density of 64 units per hectare in Mehr housing projects. If the mean dimension of urban household is considered 3.9, gross density of individual per hectare in this project will be 250. While, out of Mehr housing projects, this density in Tehran is 126 , and in other cities is 78 . We assume that urbanization standards are met, so landfill productivity in Mehr housing project will grow 220 percent from mean value. In addition, technical specification of Mehr housing projects in an area of 11500 hectare in 22 provinces were compared to desired urbanization standards, and it was specified that near 55 percent of projects were allocated to non-habitation application and it shows the sufficient attention to the urbanization and urban life standards. The important point is allocation of $14 \%$ of Mehr housing lands to greenbelt application that is assessed higher than standards (Aeini, 2010).

\subsection{Mehr housing position in rusty texture}

Urban rusty texture is considered as an opportunity to overcome habitation problem and also a substitution for new cities and suburbs for Mehr houses. In fact, by directing Mehr housing to the rusty textures, two significant events will occur. First, future problems of Mehr housing will be reduced to the minimum, the way to achieve the goals will be paved, and on the other side, by regenerating rusty texture, one of the greatest problems of urban textures will be diminished (Nasiri Taj Abadi, 2011). 


\subsection{Urban rusty textures}

The first and the most important recommended solution of this project to overcome the habitation problem in Iran is special attention to the urban rusty texture and its replacement by suburbs and new cities. On the other hand, this project tries to say that, if Mehr housing is implemented in urban rusty textures, then in addition to solve demand problem toward Mehr housing, a mutation will occur in house production (Nasiri Taj Abadi,2011).

\subsection{Mehr housing, an efficient substitution}

In Mehr housing project, 140 million Rials has been considered for each house with an area of $75 \mathrm{~mm}$. If this amount of loan is allocated to houses in rusty textures, then each unit in rusty texture requires meeting 210 million Rials by applicant. Mehr housing implementation will impose over 140 million Rials for government and banking system. On the other side, if the project is successfully implemented, then there will be the risk of welcoming production units that impose excess costs to the government. While, Mehr housing implementation in rusty textures has none of aforementioned costs and risks, except allocated loan; and this is the greatest advantage of the recommended project (Infrastructures Engineering, 2008-2009).

\subsection{A comparison between Mehr housing production cost in Tehran rusty textures and triple cities}

The cost of establishing Mehr housing in Tehran rusty textures includes preparation costs in addition to building costs. If the cost of collapse and destruction in rusty textures is considered equal to the cost of preparation in suburbs, then the difference of Mehr housing prices in rusty textures will be reflected in habitation cost (Yeganegi Dastegerdi, 2010).

\subsection{Mehr housing role in targeting subsidies}

By execution of targeting subsidies law in 2010, inflation rate has only increased 2 percent that is due to the payment of construction facilities, supplying governmental lands in the market, and special support of central bank for Mehr housing project. Continuous support for Mehr housing can compensate the reduction of economic growth arises from law execution. Furthermore, demand for energy consuming building stuff such as bricks, steel, stucco, and cement can be decreased by directing Mehr housing facilities toward industrialization.

By increasing the level of provided employment in Mehr housing project among low and middle income groups of people, people vulnerability during the execution of targeting subsidies law can be reduced. Reduction of habitation cost share in cost basket of household by Mehr housing make the share of energy cost in cost basket of household to increase because of subsidized energy carrier price modification and the implementation of targeting subsidies law will be more possible (Dehghan,2010).

\subsection{The impact of targeting subsidies on living cost of Mehr housing habitant in Tehran}

Targeting subsidies leads to increase the price of transportation. Therefore, low income people try to live in city center. Thus, the planning in Tehran is such that Mehr housing, that was considered for low income people, is established out of Tehran in 3 suburb cities, and this imposes excess costs to low income people and wastes their times to transport between Tehran and these three cities and consequently more traffic. The wasted time due to the far distance between workplace and home and excess cost of transportation can be calculated by the use of monetary equivalent estimation. According to the collected data, if the average time for each reciprocating trip is about 2 hours, and total 4 hours for traffic between home and workplace, and people travel 30 days of the year between Tehran and triple cities, then each person, at least, wastes 1240 hours annually between workplace 
and home. On the other hand, traveled distance between workplace and home for each person is equal to the distance that a person travels in the new city to reach station (is assumed to be $3 \mathrm{~km}$ ).

Table 1

The distances that individuals travels daily between workplace and home has been shown in

\begin{tabular}{ll}
\hline City & Distance between city center and Tehran \\
Hashtgerd & $65+3+20=88$ \\
Parand & $35+3+20=58$ \\
Pardis & $30+3+20=53$ \\
\hline
\end{tabular}

If the average lifetime of each Tehran citizen is considered about 50 years, then total wasted hours of Mehr housing habitant in triple cities, between workplace and home, will annually be equal to the lifetime of 453 citizens from the birth to the death. Total traveled distance by each people annually will be 11.1 billion $\mathrm{km}$ that is equal to 74 times of the distance between the sun and the earth. On the other hand, it is assumed that, after targeting subsidies and increase of energy carriers prices, each person pays 30000 Rials more than Tehran habitants for transportation. Regarding to the capitation of people travels to Tehran ( 2 people), and the assumption of 310 working days per year, a cost over $18,600,000$ Rials will be imposed to each household, annually. This cost is apart from the monetary equivalent of wasted time that people can be paid for these hours. If each of the habitant of suburb cities is paid 40000 Rials per hour in average, according to the 2 more hours than Tehran habitants, each household lose 49,600,000 Rials, annually. On the other side, assuming a constant cost in coming years, the habitants of Mehr housing in suburbs pay 68 million Rials more than Tehran habitants do, annually. This cost is only a part of damages that is forced to the households living in suburbs (Yeganegi Dastegerdi, 2010).

\section{Adaptive comparison between massive housing production in Iran and Germany}

\subsection{Investigating the status of lands in Iran and Germany}

\section{Germany}

Since many years ago, developed countries have controlled demands and supplies of lands to develop urban society using preparations such as land policy strategy and land bank leverage. Germany is also included. Although land is under private possession, but local government allows mayoralties to buy lands that are agricultural through severe control of applications and issuing construction and purchase permits for agricultural lands, which are appropriate for future development of the city and they have now lower price due to their agricultural application. Therefore, they prevent from increase of such lands' prices that usually occurs after categorizing them as lands for urban applications. Since activities related to governmental and private lands are performed in free market conditions, provincial and local government can influence on market decisions through land storage, and deal with hoard. According to the statistics, the market price of prepared lands has increased 10 to 30 percent annually from 1977 to 1983, and has decreased in 1984(Zareian, 2011).

\section{Iran (Mehr housing)}

Elimination of land price in building Mehr housing reduces the effective demand for land. Apart from psychic effect on land price reduction, it reduces the price of lands through decrease of demand. According to the reports of Iran statistics center, the average price of land in 2008 over 22 districts of Tehran was 15433.5 Rials per mm, and this price was 13936.7 Rial in 2009. Although there are several factors that affect the price reduction, but this shows the decrease of land price after execution of Mehr housing project (Zareian,2011).

\subsection{Investigating construction technology in Iran and Germany}


A review of industrial developed countries' experiences shows that if building production wants to have the features of massive house production, despite all specific complications, it is achieved by industrial construction (Zareian,2011)

\section{Germany}

First experiences of this country about using modern technology in construction goes back to 1930s, but the use of technology in building was postponed by government, because the local officials were not familiar with its advantages, presence of unskilled and cheap foreign workers during the past decades, and preference of traditional methods than industrial one. In 1960, industrial building started to work by private sector. However, due to the industrialism of this country, industrial building happened, rapidly. In this field, production of prefabricated large concrete parts could be implied. Nowadays, industrial building in competition with manual methods is extensively active, and production of proper and light prefabricated parts has accelerated building (Zareian, 2011).

\section{Iran}

Since, the primary objective of Mehr housing project is to lower price and high speed of delivering houses, and also meeting all technical and qualitative standards and regulations, massive building was considered as a possible choice. For this purpose, the process of Mehr housing construction was executed in an acceptable trend by use of massive builders. Building industrialization was a strategy that was neglected because of improper implementation of building project in large scale and massive builders enter to industrialization (Zareian, 2011).

\subsection{Investigating labor in Iran and Germany}

\section{Germany}

The role of building sector in economic development of Germany has been unique, so that 60 percent of investments in this country during the past few years were in construction projects. Therefore, it can attract 7.1 percent of labor of this country to the building sector. Therefore, it has appropriate yield in production process (Zareian, 2011).

\section{Iran}

Since, about 17 percent of Mehr housing projects are constructed by industrial methods, using skilled labors will be increased. 15 percent growth of industrialization compared with the previous year indicates more use of skilled labors. On the other side, in Mehr housing plans, it has been regulated in the country that a volume of 1.5 million houses with gross average area of $100 \mathrm{~mm}$ should be built in 89 and 90. Therefore, total area of houses in this form is 150 million mm that can create about 2 million and 630 thousand jobs directly and 640 thousand jobs, indirectly and the total employment capacity of this project is 3 million and 270 thousand jobs (Zareian, 2011).

\section{Methodology}

The present article is in the category of applicable studies, but in terms of data collection is survey. In this article, the weaknesses and the strengths of Mehr housing is investigated according to the economic aspect. Regarding to the time and location scope of study, at first the population framework of study is determined and secondly the method of providing sample is followed. The population of this study includes all 30 experts and 7000 applicants of Mehr housing project in province of Khorram Abad. Attention to the population features, simple sampling method without substitution has been chosen and each expert or applicant is considered as a sample unit. To determine sample volume, Cochran method was used. Then, dependent and independent variables were determined, and two way of open interview to 15 experts and questionnaire among applicants were distributed to 
collect information. After determining validity and reliability of questionnaire, due to the limitation of experts' population, a questionnaire was distributed to each of them. Among applicants, questionnaires were distributed among 200 people using Cochran methods. To analyze data, descriptive-inferential statistics methods were used. In descriptive method, frequency tables and percent, the means, standard deviations, and in inferential statistics, Kolmogorov-Smirnov test were used to determine normality of variables, single sample $\mathrm{T}$ test and double $\mathrm{T}$ test were used to test study hypotheses, and content analysis was used for analyzing interviews.

\subsection{Assessment of access of Mehr housing to economic goals}

This assessment was performed by 14 indexes of, meeting urbanization and technical principles, quality of houses, national production and economic growth, family density, index of access to house, employment, investment, saving energy, landfill consumption pattern of reformation, use of urban rusty texture, paid facilities, role of targeting subsidies, satisfaction of applicants from payment way of facilities, and effect of low income people for providing financial resources. By observing above table and the means of indexes, the individuals' opinion about access of Mehr housing to economic goals is estimated 3 , which is medium.

\section{The results of assessing the hypothesis of access to economic goals}

Since the variable of access to economic goals has normal distribution, single sample parametrical T test was used to test hypothesis. If we assume that:

$\mu$ : The real mean of achieving economic goals in given population

a) Applicants' opinion

\section{Table 2}

Single sample $\mathrm{T}$ test results to investigate achieving economic goals

\begin{tabular}{llll}
\hline Mean & Standard deviation & Statistic t & Significance level of test \\
\hline 2.91 & 0.503 & -2.58 & 0.99 \\
\hline
\end{tabular}

As it can be seen from Table 2, since significance level is 0.99 , so we cannot reject zero hypothesis at level of $\alpha=5 \%$ and must accept it. It means that, from opinions of applicants, Mehr housing has not achieved economic goals.

\section{b) Experts' opinion}

\section{Table 3}

Single sample $\mathrm{T}$ test results to investigate achieving economic goals

\begin{tabular}{llll}
\hline Mean & Standard deviation & Statistic t & Significance level of test \\
\hline 3.18 & 0.725 & 1.38 & 0.088 \\
\hline
\end{tabular}

As it can be seen from Table 2, since significance level is 0.88 , so we cannot reject zero hypothesis at level of $\alpha=5 \%$ and must accept it. It means that, from opinions of applicants, Mehr housing has not achieved economic goals.

c) Total

\section{Table 4}

Single sample $\mathrm{T}$ test results to investigate achieving economic goals

\begin{tabular}{llll}
\hline Mean & Standard deviation & Statistic $\mathrm{t}$ & Significance level of test \\
\hline 2.94 & 0.543 & -1.56 & 0.94 \\
\hline
\end{tabular}


As it can be seen from Table 2, since significance level is 0.94 , so we cannot reject zero hypothesis at level of $\alpha=5 \%$ and must accept it. It means that, from opinions of applicants, Mehr housing has not achieved economic goals.

\subsection{Investigation of applicant and experts' opinions' difference about achieving economic goals}

According to the normality of variable of experts and applicants' opinions about achieving economic goals, the comparison was done by using independent $\mathrm{T}$ test.

Table 5

Descriptive statistics of opinions to investigate achieving economic goals

\begin{tabular}{lll}
\hline Group & Mean & Standard deviation \\
\hline Applicants & 2.9 & 0.503 \\
Experts & 3.18 & 0.725 \\
\hline
\end{tabular}

\section{Table 6}

Comparing test to investigate achieving economic goals

\begin{tabular}{|c|c|c|c|c|c|}
\hline Statistic F & $\begin{array}{l}\mathrm{p} \text { - value of co- } \\
\text { variance test }\end{array}$ & Means difference & Statistic T & Freedom degree & $\mathrm{p}$ - value \\
\hline 3.953 & 0.048 & -0.275 & -2.618 & 228 & 0.009 \\
\hline
\end{tabular}

According to the above table, since significance level is 0.009 , so we omit zero hypothesis at level of $\alpha=5 \%$ and accept it. It means that, there has been a different.

\section{Conclusion}

In this paper, we have tried to detect weakness and strengths of Mehr housing project in Iran. There have been different weaknesses in implementation of Meh housing project including no proper design and technical justification of projects, no attention to the regional and climate, using only 2 rusty textures despite of several rusty textures. In addition, no appropriateness between habitation facilities and building costs, slowness of project due to the disability of low income people to provide cash flow and decreasing the quality of projects to compensate economic costs from targeting subsidies are among other weakness detected. There are some advantages associated with the implementation of this project such as utilization of scale economy and low cost homes for needy and young couples faced weakness in urbanization and technical principles. In addition, quality of houses, national production and economic growth, family density, index of access to house, employment, investment, saving energy, landfill consumption pattern of reformation, use of urban rusty texture, paid facilities, role of targeting subsidies, satisfaction of applicants from payment way of facilities, and effect of low income people for providing financial resources are among other issues discussed in this paper.

Therefore, by testing the main hypothesis of research, findings have indicated that Mehr housing had not achieved its economic goals. The individuals' opinion about access of Mehr housing to economic goals was estimated 3, which was medium.

\section{Recommendations}

Solutions to achieve economic goals

1- Giving priority to Tehran rusty textures, in order to build construct and convert rusty texture to storage landfills due to the advantage of being inexpensive than suburbs,

2- Directing Mehr housing facilities to industrialization, mainly to reduce demands for using energy consuming building stuff such as bricks, steel, stucco, and cement, 
3- Training implementation style by experts,

4- Produce building components and facilities adjacent to the workhouses, instead of reducing the area and decreasing the quality of stuffs in order to reduce building price,

5- Monitoring of engineering system organization on implementation of projects and monitoring groups of civilization, architecture, and infrastructures to control the quality,

6- Using UPVC doors and windows with high quality by eliminating subsidies,

7- Compliance of borders and legal limits of city, and directing the project totally into the city, and using existing capacities to promote the average index of urban landfill productivity.

\section{References}

Aeini, M. (2010). Mehr housing: Reforming pattern of urban land application and urban quality of life promotion. Scientific Economy Quarterly of Housing and Urbanization, Ministry and Adjutancy of Housing and Building. Planning and Housing Economy Affairs, 47-48, 38. (In Persian).

Azizi. M.M. (2004).The position of housing indexes in the process of planning habitation. Beautiful Arts Publication, 17, 32. (In Persian).

Azizi, M. M. (2004). Analyzing the position and changes of urban housing indexes in Iran. Beautiful Arts Publication, 23, 33. (In Persian).

Chegini, A. (2010). Effect of Mehr housing on economic indexes. Scientific Economics Quarterly of Housing and Urbanization Ministry and Adjutancy of Housing and Building, Planning and Housing Economy Affairs, 47-48,25-29. (In Persian).

Dehghan, M. (2010). Mehr housing prosperity, the condition of continuous success in targeting subsidies. Center of Technologic Studies of Science and Industry University, ( http://www.maskannews.ir). (In Persian).

Infrastructures Engineering (2008-2009). Rusty Texture, The Position Of Mehr Housing. Infrastructures Engineering, 1(6), 70. (In Persian).

Janfeshan, P. (2010). Mehr housing and future vision of habitation. Golestan Symbol Quarterly, 14, 12.

Khajepour, M. (2011). Mehr housing, A new opportunity for culture and changing the attitude of industrial building. Economic Abrar Newspaper, 102(68),102. (In Persian).

Nasiri Taj Abadi. M. (2011). Attention to the urban rusty textures in Mehr housing projects. Economy Contraption Research Institution.

Nikzadfar, K.(2011).Universal experiences of building industrialization. Economy World Newspaper.10-14. (In Persian).

Peyvandi. H, \& Dadashi. H. (2009). Mehr housing and energy saving. Appendix of Consultant Engineers of Architecture and Urbanization. (http://www.beronza.com).

Peyvandi, H., \& Dadashi, H. (2009). Solutions for energy saving-water in Mehr housing projects. Appendix of Consultant Engineers of Architecture and Urbanization.(http://www.beronza.com).

Planning and Housing Economy Affairs (2010). Mehr housing: A new approach to the habitation. Scientific Economy Quarterly of Housing and Urbanization Ministry and Adjutancy of Housing and Building, Planning and Housing Economy Affairs, 47-48, 20. (In Persian).

Soomelou. A. (2010). Structural turning in housing policies and its Achievements. Scientific Economy Quarterly of Housing and Urbanization Ministry and Adjutancy of Housing and Building, Planning and Housing Economy Affairs, 47-48,7-8.

Varesi, H. (2009). Investigation of factors affecting house price using price Hedanic model (Case Study:District3 Of Yazd). Geography And Environmental Studies Quarterly, 1(3), 6. (In Persian).

Yeganegi Dastegerdi,V. (2010). Effect of targeting subsidies on the income of Mehr housing habitants in Tehran.Urban Economy Quarterly, 8, 64-65. (In Persian).

Zareian. M. (2011). The housing production in Iran and Germany with a view Mehr housing. Panjereh magazin, 9. (In Persian). 